\title{
構造物へのエネルギー入カに着目した パルス波の衝撃的効果の評価
}

\author{
山本 大喜 1 能島 暢呂 2 \\ 1 学生会員 岐阜大学大学院 自然科学技術研究科修士課程（一501-1193 岐阜県岐阜市柳戸 1-1） \\ E-mail: w4523027@edu.gifu-u.ac.jp \\ 2 正会員 岐阜大学教授 工学部社会基盤工学科（† 501-1193 岐阜県岐阜市柳戸 1-1） \\ E-mail: nojima@gifu-u.ac.jp
}

\begin{abstract}
本研究は, エネルギー入力に着目した地震動の継続時間を定義し，パルス波がもたらす衝撃的効果の特 徵を評価する手法を提案するものである. 2016 年熊本地震本震の KiK-net 益城, 西原村小森記録では, 卓 越周期において短継続時間となった。また長周期領域において最大速度応答に達する時刻が早く, 周期に よらずほぼ同時刻となり，かつ，速度応答スペクトルは広い長周期帯域で高水準かつフラットな形状とな った。この衝撃的効果はパルス波の一種の特徴であると考えられる。また振幅特性・経時特性の双方を考 慮し, 複数の記録間で比較を行った。長周期領域において, KiK-net 益城, 西原村小森, K-NET 小千谷 (2004 年新潟県中越地震)，JMA 神戸（1995 年兵庫県南部地震）では衝撃的効果が優勢であることを明 らかにした。
\end{abstract}

Key Words: pulse wave, impulsive effect, velocity response, energy input, duration

\section{1. はじめに}

内陸地殼内地震の震源断層近傍では，パルス状の波形 が観測されることがある 1),2). 2016 年熊本地震本震でも 特徵的なパルス状の波形が観測され，より一層関心が高 まっている，文献 2)では，パルス状の速度波形の成因と して, (1) 断層の破壊フロントの伝播に伴って破壊進行 方向において生じる指向性効果によるものと，(2)フリ ングステップ (断層すべりの変位運動によって生じるス テップ状の変位波形）に起因するもの，の 2 種類を挙げ ている.いずれの要因が支配的となるかについては，観 測地点と断層との距離や位置関係，および，断層長さや すべり速度時間関数の形状などに依存する ${ }^{1)}$.

こうしたパルス状の地震動によって, 想定外の構造物 被害が発生する可能性がある. 例えば，パルス性地震動 による衝撃が免震装置の想定を上回り，建物が擁壁に衝 突し上部構造が損傷する可能性が指摘されている ${ }^{3)}$. 2016年熊本地震では，阿蘇市で設計時に想定した変位を 超える応答を生じた免震材料があったことが報告されて (る ${ }^{4)}$.また，フリングステップによる大変位を受ける 建物の転倒などの被害も考えられる ${ }^{2)}$. このように構造 物への被害が予想されることから，1995年兵庫県南部地 震以降，様々な検討がされてきた 5)8).
堺・川島 5は，加速度記録の主要動部分をゼロ・クロ ス点でパルスに分解し, 個別のパルスによる構造物の線 形応答について検討した．短い継続時間の直下型地震で は，単独の主要パルスのみでも全継続時間に匹敵する加 速度応答スペクトルが得られることが示された。

理想化された入力波形に対する応答特性についても検 討されている．鈴木らの，正弦波パルスに対する 1 自 由度系の最大応答を定式化し，断層近傍でのパルス性地 震動の影響を反映した設計用加速度応答スペクトルを提 案した。安井ら 7は，正弦波パルス 1 波に対する線形 1 自由度系の基本応答特性について理論的考察を行い，最 大応答とその発生時刻，および，減衰による応答低減効 果の理論解を示すとともに，設計用の簡便な近似式も提 案している.

文献 9,7の発展により実地震動をモデル化する検討も されている. 亀井ら ${ }^{8}$ は内陸地款内地震の断層近傍で発 生する観測波から $\sin$ 波およびGabor波で模擬したパルス 波モデルを求め，周期や振幅等のパルス特性を評価する 方法を提案した．2016年熊本地震の観測波（断層平行成 分，断層直交成分）のパルス特性を評価した。また，観 測波に対する高層建築物の層間変形角応答特性について も，複数のパルス波モデルの応答特性によって解釈でき ることを示した. 
これらの研究5-8)では正弦波パルスやGabor波でモデル 化された入力波形に対する応答特性に関して極めて重要 な知見が得られており，その評価手法も確立され始めて いる. しかし，振幅と周期が経時的に変化する実地震動 としてのパルス状の波形が広帯域にわたって様々な構造 物応答に与える影響については十分に議論されておらず, その評価方法の検討には至っていない.

このため著者ら 9は，パルス波の振幅，作用方向，夕 イミングに着目し，構造物の応答に及ぼす影響について 考察した. 加速度の振幅と符号, および，速度応答の振 幅と符号との複合的作用が応答を支配することを明らか にした．しかし，パルス波がもたら寸動的効果（衝撃的 効果，共振的効果）に関しては定量的に評価する余地が あり, 今後の課題としていた.

本研究においては, 最大応答に達寸るまでの動的過程 に着目し，「構造物の固有周期に関わらずごく短時間で 最大応答に至らせるパルス波の動的効果」を「衝撃的効 果」と定義する。これと対比させて, 過渡応答 ${ }^{10)}$ を経て 徐々に応答が発達して最大応答に至る動的効果を「共振 的効果」と定義する. 本研究では, 衝撃的効果を表す指 標としてエネルギー入力に基づく継続時間を用い，その 定量的評価方法について検討を行う。

なお既往研究においては，「パルス性地震動」，「パ ルス状の波形」，「長周期パルス」など様々な用語が用 いられているが，以下，本研究においては，大振幅のパ ルス状の実地震動波形を統一的に「パルス波」と呼び, それを構成する片振幅の半波成分を「パルス」として区 別する.

\section{2. 本検討で使用する観測記録}

今回の検討では, 4 つの内陸地款内地震での以下の記 録を用いた評価事例を示寸.

• 2016年熊本地震 (本震, 2016 年 4 月 16 日, $M=7.3$ )

KiK-net益城（KMMH16，EW 成分）

西原村小森（EW 成分）

K-NET一の宮（KMM004，EW成分）

• 1995 年兵庫県南部地震（1995 年 1 月 17 日, $M_{F}=7.3$ )

JMA 神戸 (NS 成分)

·2004年新潟県中越地震 $(2004$ 年 10 月 23 日, $M=6.8)$

K-NET 小千谷 (NIG019, EW 成分)

- 2007 年新潟県中越沖地震 $(2007$ 年 7 月 16 日, $M=6.8$ )

K-NET柏崎（NIG018，EW成分）

図-1にそれぞれの加速度波形を示寸．いずれも主要動 部分の継続時間は $10 \mathrm{~s}$ 程度以下と短い記録である. KiKnet 益城，西原村小森，JMA 神戸，K-NET 小千谷は大振 幅のパルスが顕著に見られる点で類似している．K-NET

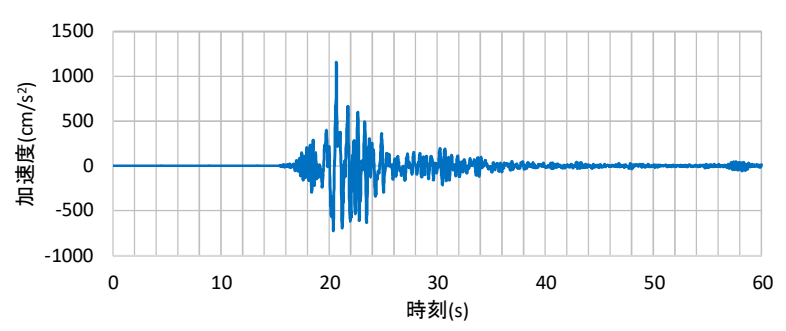

(a)KiK-net益城（KMMH16, EW 成分, 2016年)

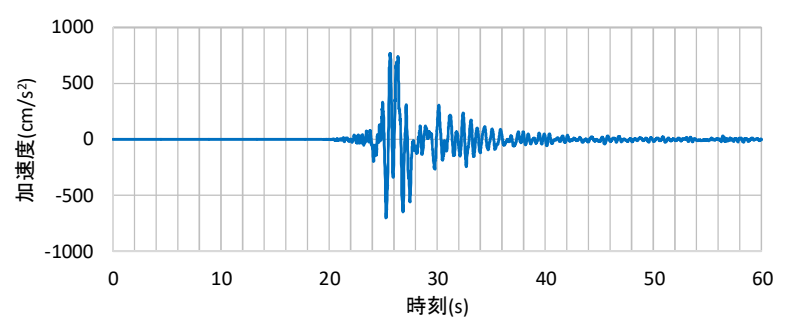

(b) 西原村小森（EW 成分，2016年）

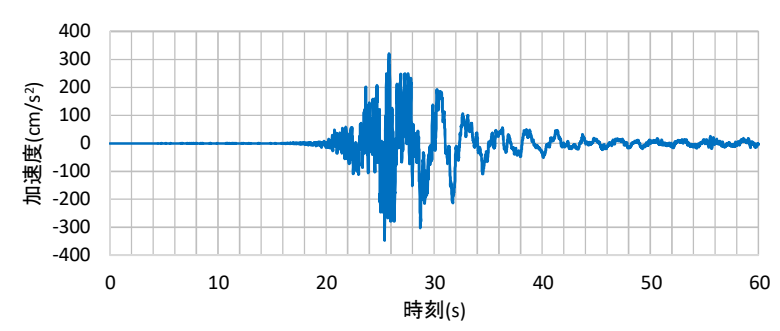

(c)K-NET一の宮（KMM004，EW成分，2016年）

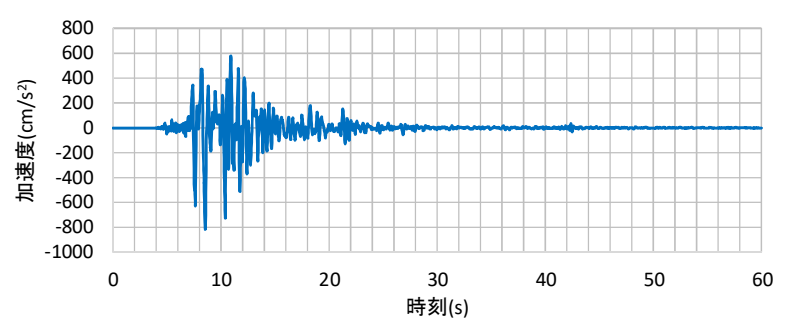

(d) JMA 神戸（NS 成分，1995 年）

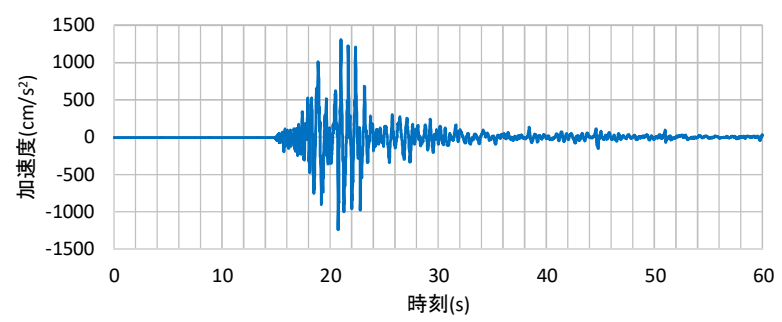

(e)K-NET 小千谷（NIG019, EW 成分, 2004年)

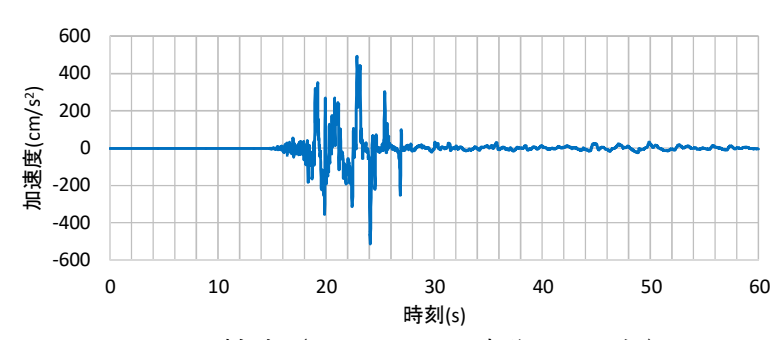

(f)K-NET 柏崎（NIG018，EW成分，2007年)

図-1 対象とする加速度記録 


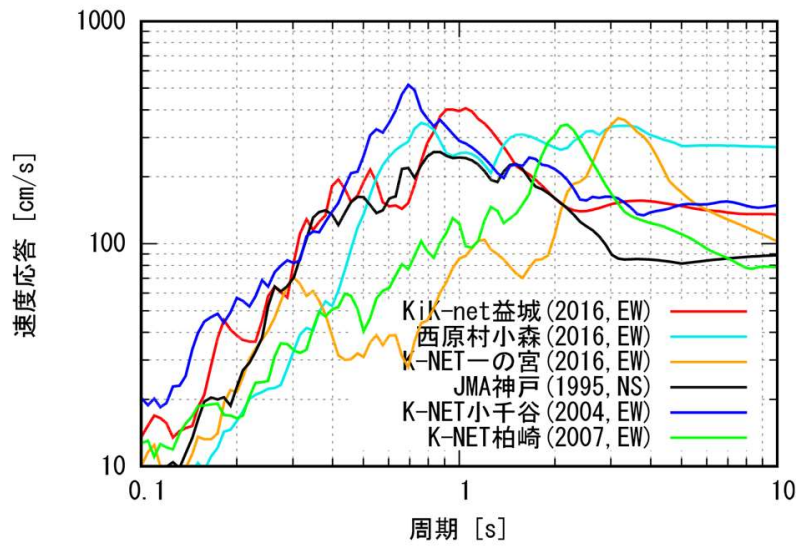

図-2 速度応答スペクトル

一の宮は波形前半で短周期成分，後半で長周期成分が目 立っている. K-NET柏崎はスパイク状のパルスが特徴的 である.これはごく表層の液状化等の影響によるもので はなく, 周辺地域を代表する地震動と考えられている ${ }^{11)}$. 図-2に速度応答スペクトルを示す，卓越周期は上記順に $T=1.05 \mathrm{~s} ， 0.76 \mathrm{~s} ， 3.16 \mathrm{~s} ， 0.87 \mathrm{~s} ， 0.69 \mathrm{~s} ， 2.19 \mathrm{~s}$ である.

以下，3.では経時特性に着目した動的効果の定量化に ついて検討する．4.では 2016年熊本地震本震における上 記の 3 記録にこの手法を適用して詳細な評価を行う。さ らに 5.では, 経時特性と振幅特性の両面を考慮した評価 方法を検討する. 他の 3 地震の記録も加え，複数の記録 を用いた比較について示す.

\section{3. 経時特性に着目した動的効果の定量化}

本章では，入力波形と相対速度応答との関係によって 規定されるエネルギー入力の考え方 ${ }^{12}$-17〕基づいて継続 時間を算出する方法について検討する. なおここでは, 2016年熊本地震本震における KiK-net益城（EW 成分）の 観測記録を用い，継続時間の算出例を示す.

\section{(1) 線形 1 自由度系への地震動のエネルギ一入力}

線形 1 自由度系の振動の運動方程式は次式で表される。

$$
m \ddot{y}+c \dot{y}+k y=-m \ddot{z}_{0}
$$

ここに, $m$ : 質点の質量, $c$ : 減衰係数, $k$ : 剛性, $y$ : 質点の相対変位, $\ddot{z}_{0}$ : 地動加速度 である. 式(1)の両辺 に微小時間 $d \tau$ における変位増分 $d y=\dot{y} d \tau$ を乗じて時刻 0 から $t$ まで積分して $m$ で除すと, 次式(2)が得られる.

$$
\int_{0}^{t} \ddot{y} \dot{y} d \tau+2 h \omega_{0} \int_{0}^{t} \dot{y}^{2} d \tau+\omega_{0}^{2} \int_{0}^{t} y \dot{y} d \tau=-\int_{0}^{t} \ddot{z} 0 \dot{y} d \tau
$$

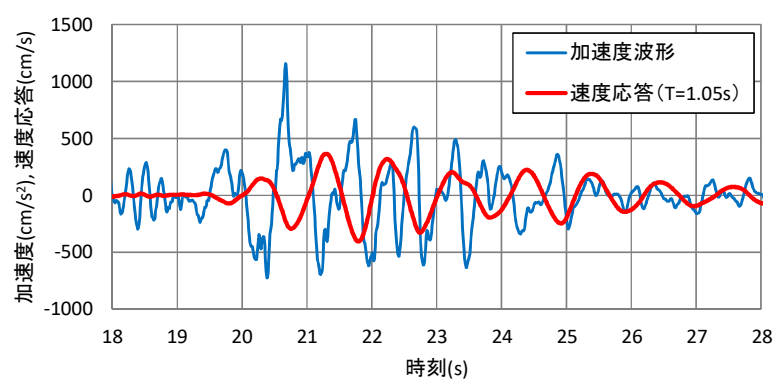

(a) 地動加速度 $\ddot{z}_{0}$ と速度応答 $\dot{y}$

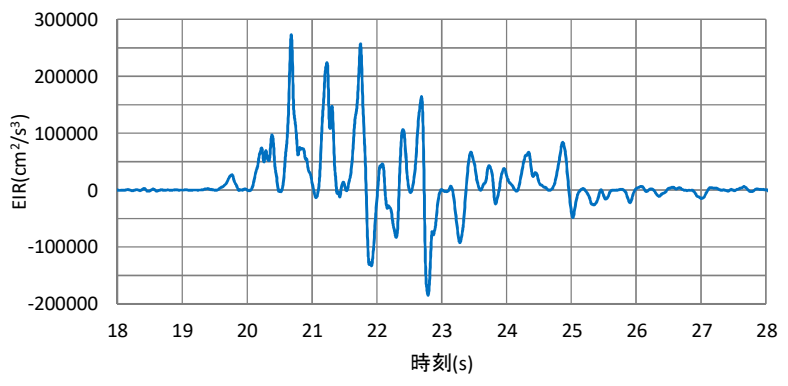

(b)エネルギー入力率 $e$

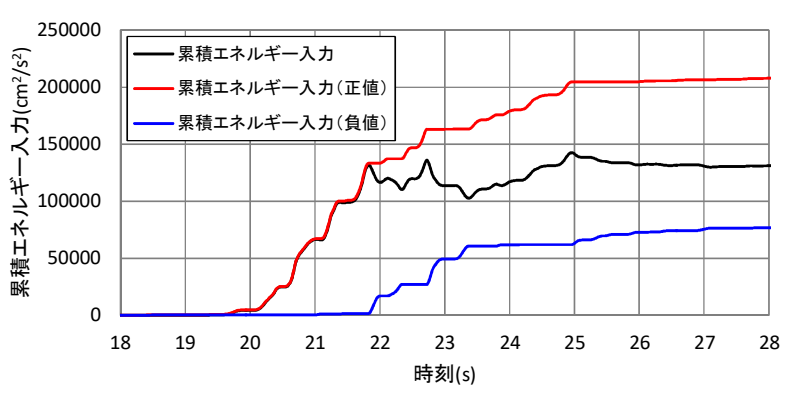

(c)累積エネルギー入力 $E$

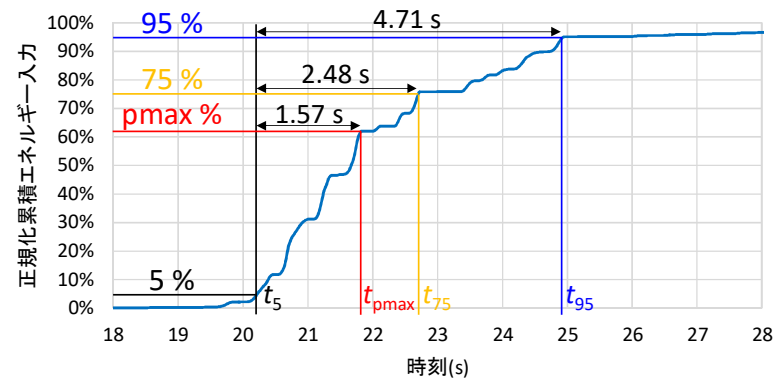

(d) 正規化累積エネルギー入力および継続時間の算出例

図-3 継続時間の算出例 (KiK-net益城, KMMH16, EW 成分, $T=1.05 \mathrm{~s}, \quad h=0.05)$

ここに, $\omega_{0}=\sqrt{k / m}$ : 固有円振動数, $h:$ 減衰定数 で ある. 式(2)は，単位質量あたりのエネルギーの釣り合 い式 ${ }^{12)}$ 17)を表しており，その右辺は地震動が時刻 $t$ まで に構造物に行う単位質量あたりの仕事 ${ }^{12}$-17)（累積エネル ギー入力）を表し，その時間微分はエネルギー入力率 (EIR: Energy Input Rate)（仕事率）を表す ${ }^{14}$. 


$$
\begin{gathered}
E(T, t)=-\int_{0}^{t} \ddot{z}_{0}(\tau) \dot{y}(T, \tau) d \tau \\
e(T, t)=\dot{E}(T, t)=-\ddot{z}_{0}(t) \dot{y}(T, t)
\end{gathered}
$$

また，総累積エネルギー入力の速度換算值は「エネルギ 一スペクトル」と呼ばれる ${ }^{12,131,151717 .}$

$$
V_{E}(T)=\sqrt{2 E\left(T, t_{\text {end }}\right)}
$$

ここで，tend は記録の最終時刻である.

図-3(a) 図-3(c)に KiK-net益城（EW 成分）の速度応答 スペクトル (図-2 参照) の卓越周期 $T=1.05 \mathrm{~s}$ を対象とし て $h=0.05$ としたエネルギー入力に関する結果の例を示す. 図-3(a)において時刻 $t=20.7 \mathrm{~s}$ の速度応答の局所的ピーク時 に逆方向の最大加速度（順方向の最大慣性力）が作用寸 ることで, 図-3(b)のエネルギー入力率 $e$ は急激に最大值 に達している.これを挟んだ時刻 $t=19.5 \sim 21.8 \mathrm{~s}$ の間は, $e$ がほぼ正值を保ち，図-3(c)に黒線で示す累積エネルギ 一入力 $E$ が急増している. 最大速度応答が生じた時刻 $t=21.8 \mathrm{~s}$ では, 最終的な累積エネルギー入力とほぼ同值に 達している，この間，およそ 2 秒間の現象であり，衝撃 的な加速度入力による短時間内の応答増幅効果を示して いる. 時刻 $t=21.8 \sim 23.5 \mathrm{~s}$ において， $e$ は負值が支配的で $E$ は平均的に減少しており，速度応答は抑制されている。 時刻 $t=23.5 \sim 25 \mathrm{~s}$ では再び $e$ は正值が支配的となり $E$ は増 加するが，上記ほど急激ではなく，応答増幅には結びっ いていない。このように，ある瞬間における，加速度の 振幅と符号，および，速度応答の振幅と符号との複合的 作用が，エネルギー入力としてその直後の応答を支配す る9.

\section{（2）正規化累積エネルギ一入力に基づく継続時間の算 出方法}

正規化累積パワー18)（“Husid plot”と呼ばれる）は以下 の式で与えられる.

$$
P_{C}(t)=100 \cdot \frac{\int_{0}^{t} \ddot{z}_{0}^{2}(\tau) d \tau}{\int_{0}^{t}{ }_{\text {end }} \ddot{z}_{0}{ }^{2}(\tau) d \tau}
$$

これに基づく継続時間 (Significant duration)は，一般的な経 時特性指標である. 正規化累積パワーにおける 5 95\% の占有時間（波形全体の傾向を表す）もしくは 5 75\% の占有時間（主要動部あるいは実体波の傾向を表す）が よく用いられる ${ }^{19}$.

式(6)は加速度波形そのものの経時特性を表す一方, 本研究では，パルス波が構造物への応答に及ぼす影響に 主眼を置いているため，構造物の周期特性と関連付けた

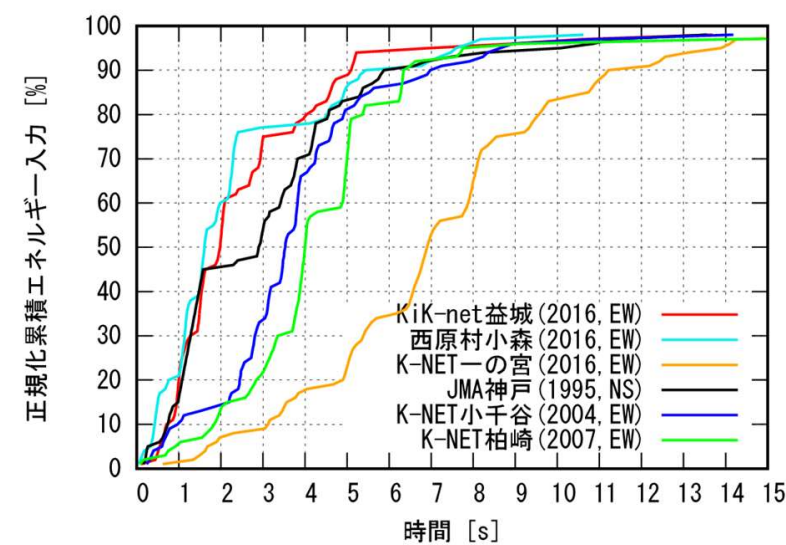

図-4 卓越周期における正規化累積エネルギー入力の比較 ( $t_{1}$ を 0 sに揃えて表示)

経時特性指標が必要である。そこで，式(6)の正規化累 積パワーの考え方を式(3)の累積エネルギー入力に適用 し，継続時間の算出を試みる。ここで，式(6)が単調増 加関数であるのに対して, 式(4)の EIR は負值にもなり得 るため, 累積エネルギー入力は単調増加関数とはならな い. 従って, その逆関数は多価関数となり, パーセンタ イル值が一意に定まらない，そこで，EIR を符号に応じ て分離し，図-3(c)に示寸ように正值部分のみの累積エネ ルギー入力 $P_{E+}$ および，負值部分のみの累積エネルギー 入力 $P_{E-}$ を求める.

$$
\begin{gathered}
P_{E+}(T, t)=\int_{0}^{t} \max \left\{-\ddot{z}_{0}(\tau) \dot{y}(T, \tau), 0\right\} d \tau \\
P_{E-}(T, t)=-\int_{0}^{t} \min \left\{-\ddot{z}_{0}(\tau) \dot{y}(T, \tau), 0\right\} d \tau
\end{gathered}
$$

このうち，式(7)の正の累積エネルギー入力に着目し， これを正規化したものを「正規化累積エネルギー入力 $H_{E^{+}} 」$ とする (図-3(d)参照) .

$$
H_{E+}(T, t)=100 \cdot \frac{P_{E+}(T, t)}{P_{E+}\left(T, t_{\text {end }}\right)}
$$

式(9)の正規化累積エネルギー入力を $1 \%$ 刻みで離散化し， 99個のパーセンタイル值を求める ${ }^{20)}$.

$$
t_{i}=H_{E+}{ }^{-1}(i) \quad(i=1, \ldots, 99)
$$

図-1の 6 波形を用いて，それぞれの卓越周期における 正規化累積エネルギー入力の比較を図-4に示寸 (卓越周 期は図-2を参照）。ここでは， $t_{1} を 0 s$ に揃えて示してい る. KiK-net 益城, 西原村小森, JMA 神戸の開始部分の 立ち上がりが急激であり，KiK-net 益城，西原村小森で は 3s 程度で約 70\%まで達している，K-NET 小千谷，K- 
$\mathrm{NET}$ 柏崎では始めの 2s 程度は緩やかな立ち上がりであ るが，その後急増する．K-NET一の宮は全体を通して緩 やかな増加を示す.

これらの正規化累積エネルギー入力を用いて，その $a \% \sim b \%$ に相当する継続時間を次式で定義する.

$$
\begin{aligned}
D_{a-b}\left[H_{E+}(T)\right] & =H_{E+}{ }^{-1}(b)-H_{E+}{ }^{-1}(a) \\
& =t_{b}-t_{a}
\end{aligned}
$$

ある固有周期 $T$ の速度応答波形において，最大速度応 答に達した時刻を $t_{\mathrm{pmax}}$ とし，その時点におけるパーセン タイル值を pmax とする. 本研究では主に最大応答に達 するまでの継続時間 $D_{5-p m a x}$ に注目し， $D_{5-75}$ および $D_{5-95}$ と 比較しながら衝撃的効果についての考察を行う。図-3(d) にKiK-net益城（EW 成分）の速度応答スペクトルの卓越 周期 $T=1.05 \mathrm{~s}$ を対象とした継続時間の算出例を示す.こ のケースでは $D_{5-p m a x}=1.57 \mathrm{~s} ， D_{5-75}=2.48 \mathrm{~s} ， D_{5-95}=4.71 \mathrm{~s}$ である.

\section{(3) エネルギ一入力効率の定義}

前節で示した継続時間に加え，エネルギーの入力され る効率についても指標化を検討する. 式(5)の考え方と 同様に，式(7)および式(8)の累積エネルギー入力の最終

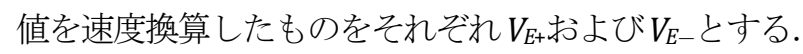

$$
\begin{aligned}
& V_{E+}(T)=\sqrt{2 P_{E+}\left(T, t_{\text {end }}\right)} \\
& V_{E-}(T)=\sqrt{2 P_{E-}\left(T, t_{\text {end }}\right)}
\end{aligned}
$$

$V_{E}$ と $V_{E+}$ を用いて「エネルギー入力効率 $R_{E} 」$ を次式で定 義する.

$$
R_{E}(T)=\frac{V_{E}(T)}{V_{E+}(T)}=\sqrt{\frac{P_{E+}\left(T, t_{\mathrm{end}}\right)-P_{E-}\left(T, t_{\mathrm{end}}\right)}{P_{E+}\left(T, t_{\mathrm{end}}\right)}}
$$

これは，最終時刻 t end において，正の累積エネルギ一入 力 (速度換算值) に対してトータルの累積エネルギー入 力（速度換算值）が占める割合を表している．所定の継 続時間を通じて，入力加速度が応答の増幅に寄与した割 合の平方根を定量化している.

本章では卓越周期のみに着目したが，4.では，より広 帯域にわたつて様々な構造物に与える衝撃的効果に関し て考察を行うため, 継続時間の表現方法を全周期帯に拡 張し, 動的効果の評価を試みる.

\section{2016 年熊本地震本震での評価例}

本章では，2016年熊本地震本震の 3 記録を扱い，対象
記録の全周期帯についての評価結果を以下に示す. (a) に速度応答スペクトル $S_{V}$ ，擬似速度応答スペクトル $p S_{V}$ ， エネルギースペクトル（トータル $V_{E}$, 正 $V_{E+}$, 負 $\left.V_{E-}\right)$ の 比較を示す. (b)にエネルギースペクトルを元に算出し たエネルギ一入力効率スペクトル $R_{E}$ を示す. (c)に時刻 $t_{i}$ (d)に継続時間 $D_{a b b}$ を示す. なお，本研究では $h=0.05$, $t_{\text {end }}=60 \mathrm{~s}$ とする.

\section{(1) KiK-net 益城 (KMMH16)（図-5, 図-6)}

図-5(a)の速度応答スペクトルの卓越周期は $T=1.05 \mathrm{~s}$ で ある. 卓越周期付近では $V_{E}$ と $V_{E+}$ が接近している。この 結果を反映し, 卓越周期付近ではエネルギ一入力効率 $R_{E}$ が 0.8 を超えている. EIR が負になることが少なく, 応答が増幅される傾向にあったことが分かる，一方，長

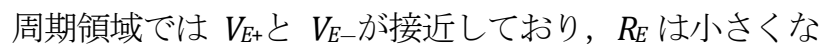
る. 入力加速度はやや短周期であるが応答は長周期であ るため, EIR が加速度の周期で正負交互に切り替わり，

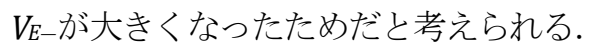

図-5(c)における青点は，周期ごとの時刻 $t_{1} \sim t_{99}$ を示し ている. 時刻 $t_{i}$ の範囲は，卓越周期付近では $t=35 \mathrm{~s}$ まで であるのに対し，短周期側および長周期側では $t=60 \mathrm{~s}$ ま でに及ぶ。青点の密度が高い時間帯では累積エネルギー 入力の急激な増加が生じたといえる. 全周期帯で $t=20$ $25 \mathrm{~s}$ 付近までの密度が高い.この $5 \mathrm{~s}$ 間は主要動部分であ り，応答が急激に増幅したといえる。図-5(c)における実 線は代表とする時刻 $t_{5}$ (黒線)， $t_{75}$ (黄線)， t $t_{5}$ （青 線)， $t_{\mathrm{pmax}}$ (赤線) である.

式(11)に従い，図-5(c)における黒線 $t_{5}$ を基準として, 黄線 $t_{75}$ まで, 青線 $t_{95}$ まで, 赤線 $t_{\text {pmax }}$ までの継続時間を それぞれ図-5(d)の黄線 $D_{5-75}$, 青線 $D_{5-95}$, 赤線 $D_{5-p m a x}$ で示 す. $D_{5-75}=2 \sim 6 \mathrm{~s}$ 程度, $D_{5-95}=3 \sim 18 \mathrm{~s}$ 程度, $D_{5-\mathrm{pmax}}=1 \sim 5 \mathrm{~s}$ 程 度である. 卓越周期付近ではいずれの継続時間も短い。

$D_{5-75}$ と $D_{5-95}$ は短周期および長周期になるにつれて徐々に 長時間化する傾向にある. 一方， $D_{5-p m a x}$ に着目すると， 長周期側ではほぼ $D_{5-p m a x}=1 \mathrm{~s}$ であり，固有周期よりもはる かに短時間である．特に固有周期 $2 \mathrm{~s}$ 以上では，ほぼ同 時刻に最大応答に達していることが分かる．正弦波パル スに対する衝撃的な応答の特徴 7が実地震動のパルス波 でも表れる結果となった. 長周期領域におけるこの現象 はパルス波による衝撃的効果の一つと言えよう.

長周期領域での応答をより詳細に考察するために, 図 -6に加速度波形および速度応答波形（長周期領域）を示 す. 黒丸は最大速度応答を表す. $T=2.00 \mathrm{~s}$ よりも長周期 側では， $t=21 \mathrm{~s}$ までの速度応答波形の位相はほぼ一致し ており, $t=21 \mathrm{~s}$ 付近で最大速度応答（いずれも約 $150 \mathrm{~cm} / \mathrm{s}$ ) に達している. $t=21 \mathrm{~s}$ 以降はそれぞれの固有周期で振動 している. 最大速度応答は大振幅パルス波が入力される $t=20.5 \mathrm{~s}$ の直後に出現している. これは，衝撃的な入力に 

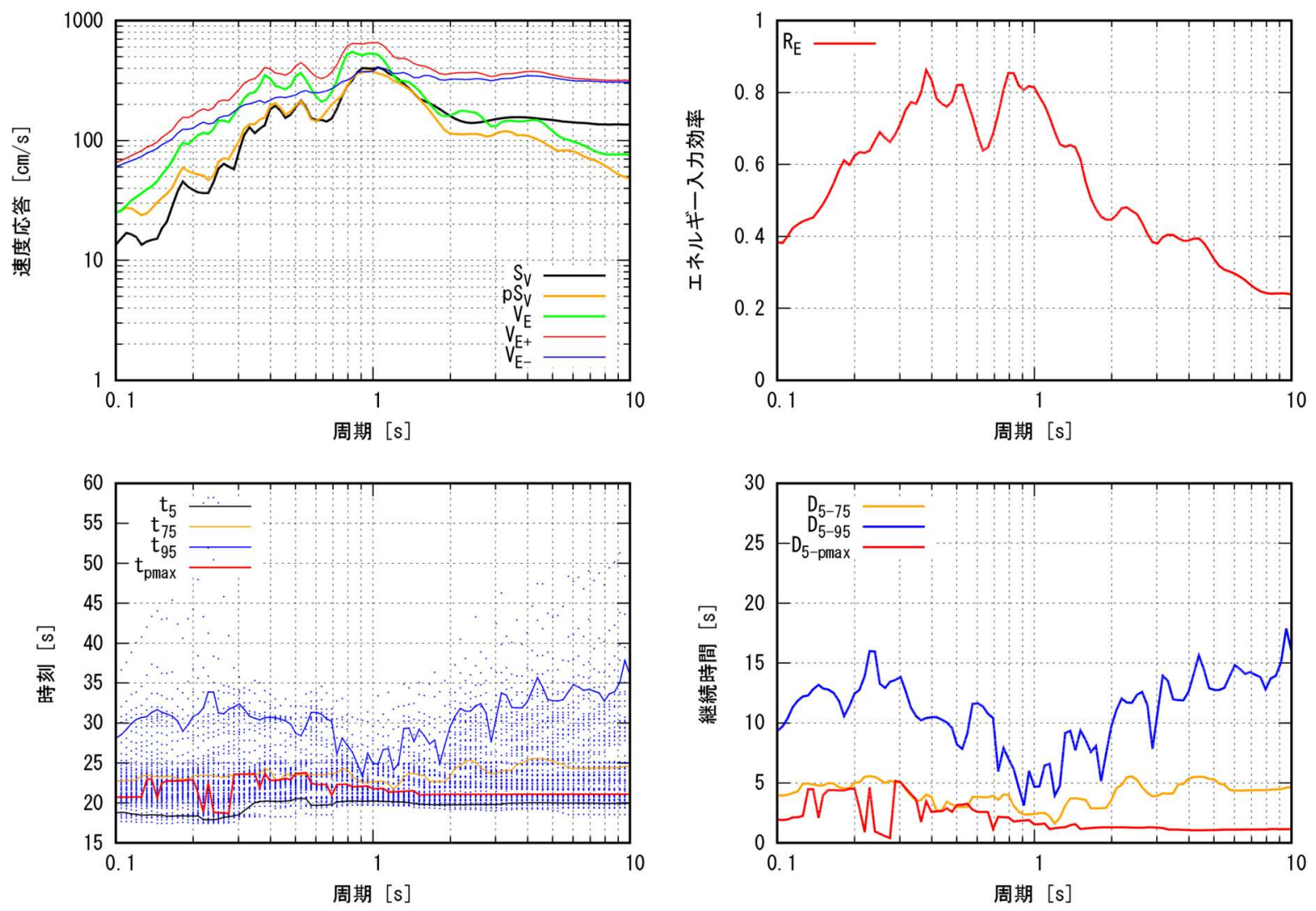

左上 : (a)スペクトルの比較，右上 : (b)エネルギ一入力効率スペクトル，左下：(c) 時刻 $t_{i}$, 右下 : (d) 継続時間 $D_{a b}$

図-5 KiK-net益城（KMMH16，EW 成分）

対しては応答が追随できず，地動速度そのものが相対速 度応答として現れることを示唆している. 一般に周期を 無限大とすると相対応答は地動と一致するが，パルス波 入力は長周期領域で広く同様のことが起き，相対応答は その衝撃的効果に支配されるものと考えられる. その様 子は図-5(a)の速度答スペクトルにも反映されており, $T=2 \mathrm{~s}$ よりも長周期側で約 $150 \mathrm{~cm} / \mathrm{s}$ で一定の值を示してい る. 速度応答スペクトル $S_{V}$ がフラットな形を示すのはパ ルス波による衝撃的効果の特徴の一つと考えられる. 擬 似速度応答スペクトル $p S_{V}$ の長周期領域ではこの特徴が 表現できておらず， $S_{V}$ と比較して過小評価となっている. パルス波が支配的な地震動記録に擬似速度応答スペクト ルを用いる際は，この点に留意すべきといえる.

\section{(2) 西原村小森（図-7, 図-8）}

図-7(a)の速度応答スペクトルの卓越周期は $T=0.76 \mathrm{~s}$ で ある。卓越周期付近において， $V_{E-}$ は周囲の周期よりか なり低く，エネルギー入力効率 $R_{E}$ はおよそ 0.9 である.

KiK-net益城よりも EIRが負になる割合が小さく，パルス 波入力が応答の増幅に大きく寄与したといえる.

継続時間は $D_{5-75}=2 \sim 7 \mathrm{~s}$ 程度， $D_{5-95}=7 \sim 16 \mathrm{~s}$ 程度， $D_{5-\text { pmax }}=$ $1 \sim 4 s$ 程度である. 卓越周期付近では継続時間が短いが, その特徴は KiK-net 益城ほど顕著ではない. $D_{5-75}$ と $D_{5-95}$

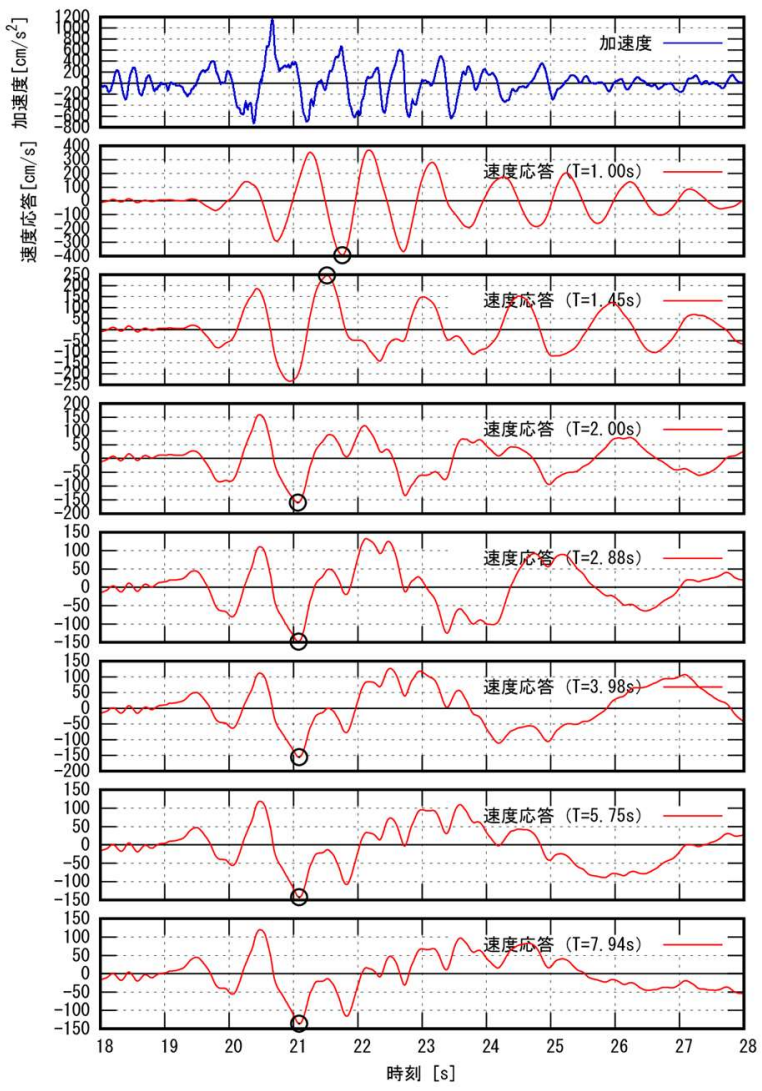

図-6 加速度波形および長周期領域における速度応答波形 (KiK-net益城，KMMH16，EW成分） 

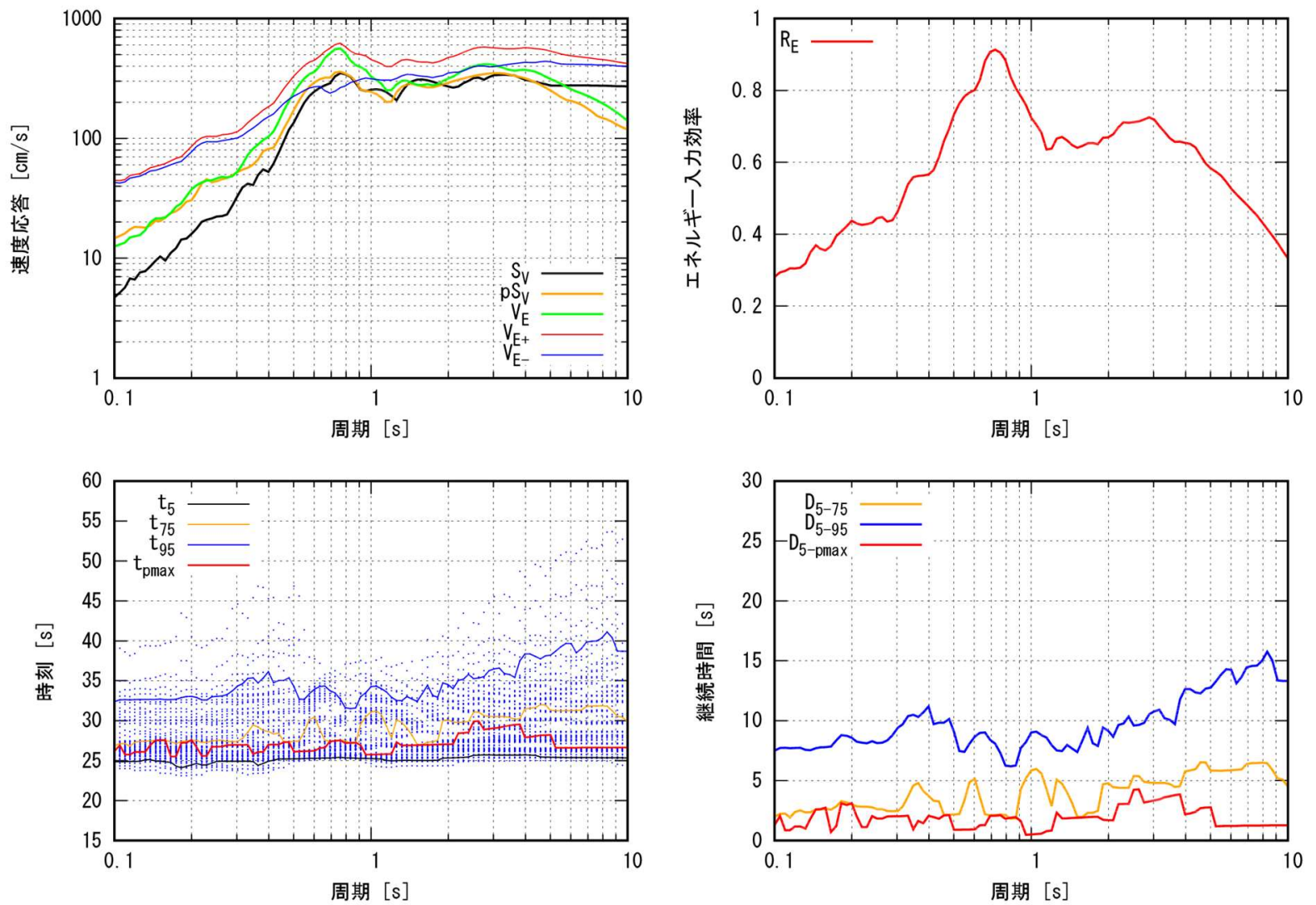

左上 : (a)スペクトルの比較, 右上 : (b)エネルギー入力効率スペクトル, 左下 : (c) 時刻 $t_{i}$, 右下 : (d) 継続時間 $D_{a b}$

図-7 西原村小森（EW成分）

は長周期側で継続時間が長時間になる傾向がある．周期 $T=1 \mathrm{~s}$ 付近および $T=5 \mathrm{~s}$ 以上については $D_{5-\text { pmax }}=1.5 \mathrm{~s}$ 末満で あり，卓越周期付近よりも純粋にパルス波による衝撃的 効果が現れていると考えられる.

図-8 に長周期領域の速度応答を示す. $T=5.75 \mathrm{~s}$ よりも 長周期側では，最大応答を含む $t=27 \mathrm{~s}$ までの速度応答波 形の位相は類似している.これは KiK-net 益城と同様に, 地動速度そのものが相対速度応答として現れていると考 えられる.これは図-7(a)の速度応答スペクトルにも表れ ており，長周期領域において約 $300 \mathrm{~cm} / \mathrm{s}$ でフラットな形 を示している. KiK-net 益城の長周期領域よりもむしろ 振幅レベルは高い.

$T=2.88 \mathrm{~s}$ では他の周期とは異なり，最大応答の出現時 刻には約 1 周期分のずれが認められる. 卓越周期 $T=0.76 \mathrm{~s}$ 付近と $T=3 \mathrm{~s}$ 付近ではほぼ同レベルの速度応答を示して いるが，図-7(d)に示すように卓越周期付近では $D_{5 \text {-pmax }}=2 \mathrm{~s}$ 程度であり, $T=3 \mathrm{~s}$ 付近では $D_{5-\mathrm{pmmx}}=4 \mathrm{~s}$ 程度である. 前者 は衝撃的効果によるものである一方，後者にはやや共振 的効果も働いたと考えられる. 図-7(b)のエネルギ一入力 効率スペクトルが $T=3 \mathrm{~s}$ 付近で大きな值を示すことは, パルス波入力と速度応答のタイミングが整合したことを 示唆し，それが共振的効果につながったと考えられる.

応答スペクトルにおいては, 最大応答の発現時刻に関 する情報が失われているため，以上に示したような継続

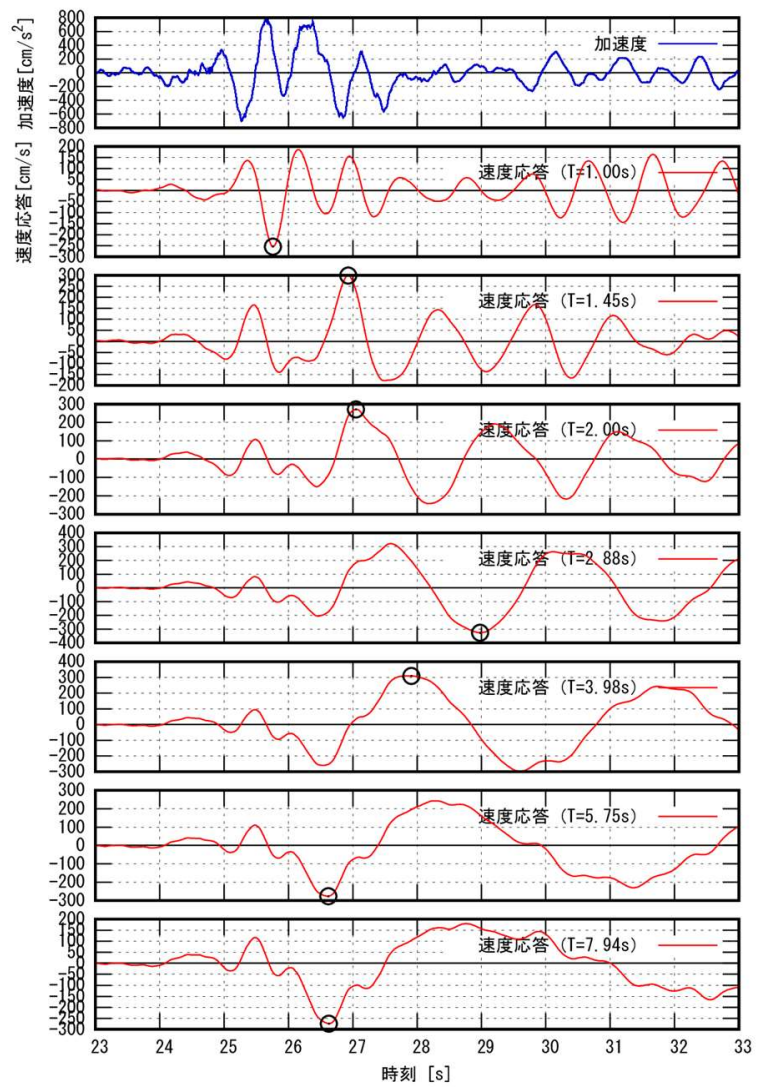

図-8＼cjkstart加速度波形および長周期領域における速度応答波形 (西原村小森, EW 成分) 

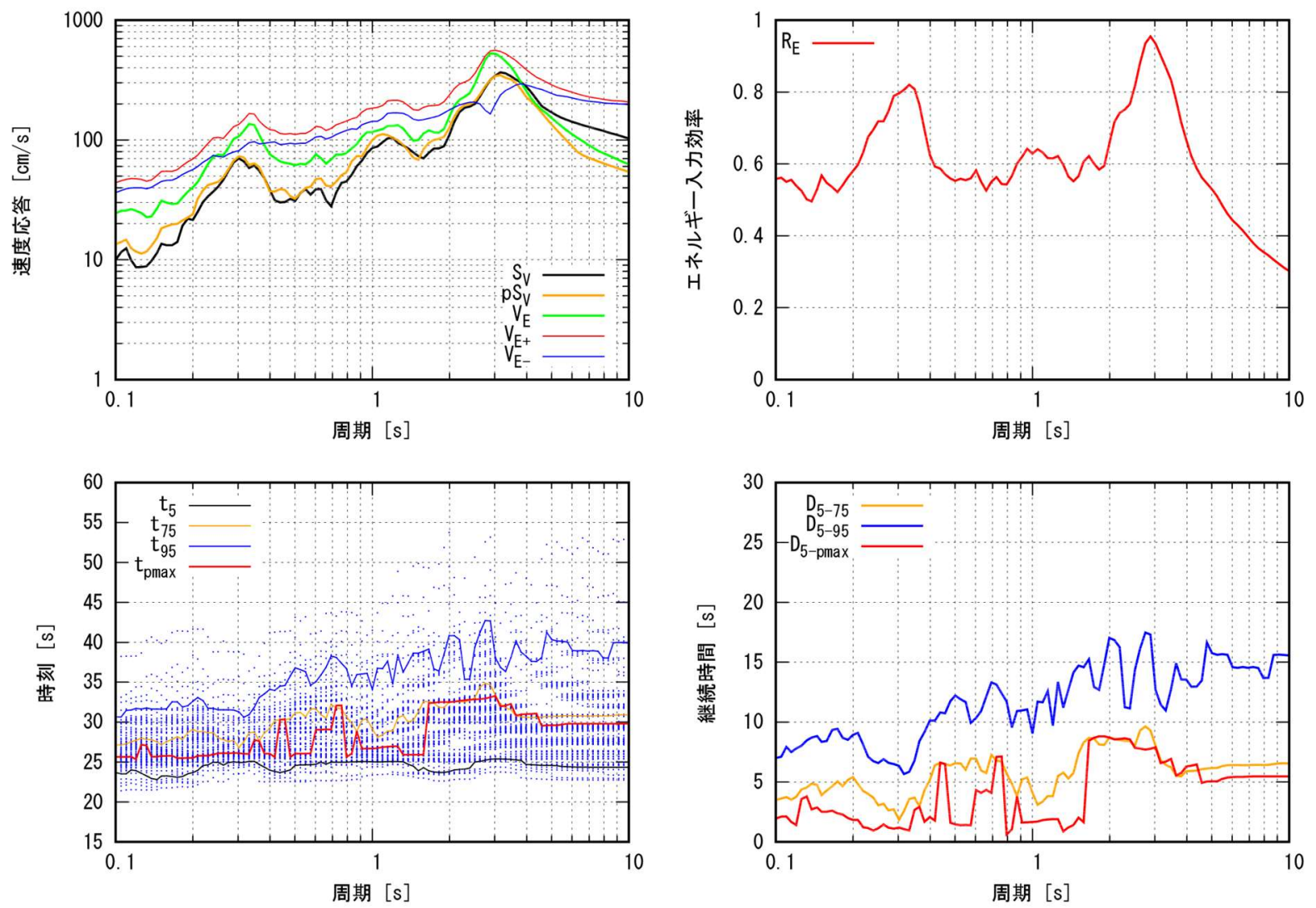

左上 : (a)スペクトルの比較, 右上 : (b)エネルギー入力効率スペクトル, 左下 : (c) 時刻 $t_{\text {, }}$ 右下 : (d) 継続時間 $D_{a b}$

図-9 K-NET一の宮（KMM004，EW 成分）

時間との比較は理解の助けになる.

\section{(3) K-NET 一の宮 (KMM004)（図-9，図-10)}

図-9(a)の速度応答スペクトルの卓越周期は $T=3.16 \mathrm{~s}$ で ある．卓越周期付近では， $V_{E-}$ は大きく落ち込んでいる. エネルギー入力効率 $R_{E}$ は， $T=0.3 \mathrm{~s}$ 付近では 0.8 を超え, 卓越周期付近では 0.9 を超える. 図-1(c)および図-10 に示 す加速度波形の前半部分と後半部分の異なった周期特性 がそれぞれに影響していると考えられる。すなわち， $T=0.3 \mathrm{~s}$ 付近では加速度波形の前半部分が，卓越周期付近 では後半部分が応答の増幅に寄与したといえる.

継続時間は $D_{5-75}=2 \sim 9 \mathrm{~s}$ 程度, $D_{5-95}=6 \sim 17 \mathrm{~s}$ 程度, $D_{5 \text {-pmax }}=$ 1 8s 程度である. KiK-net 益城や西原村小森と比較して 継続時間が長い傾向を示す. 特に $D_{5 \text {-pmax }}$ は卓越周期付近 で約 2 周期分長い継続時間である. 図-10 に長周期領域 の速度応答を示す. KiK-net 益城や西原村小森に見られ たような，速度応答波形の位相の一致や最大応答出現の 同時性は認められない．図-1(c)および図-10 の加速度波 形からもわかるように， $t=27 \mathrm{~s}$ 前後を境に周期特性が大 きく変化しており，最大応答の発現時刻が構造物の固有 周期によってばらつく結果となっている．特に卓越周期 の $T=3 \mathrm{~s}$ 付近では, 先の西原村小森と同様に, 図-9(b)の エネルギー入力効率スペクトルが大きくなっており，共 振的効果のために最大応答の出現が後にずれ込んだと考

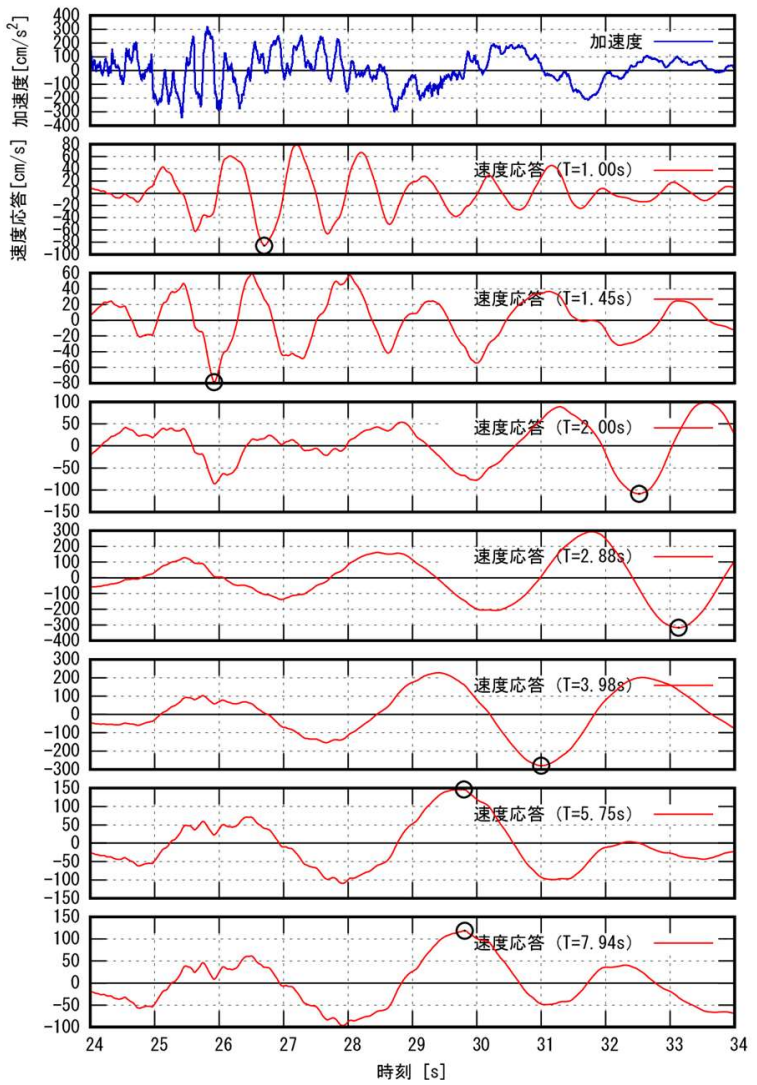

図-10 加速度波形および長周期領域における速度応答波形 (K-NET一の宮, KMM004，EW 成分） 


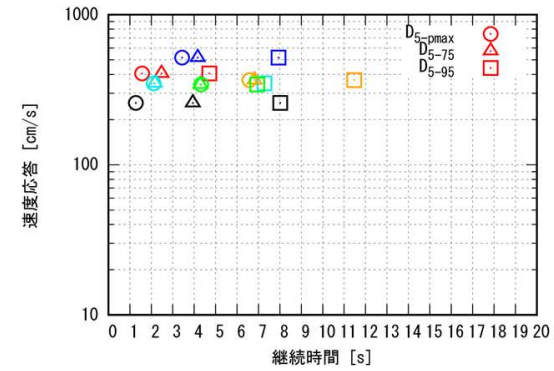

(a) 各波形の卓越周期における結果

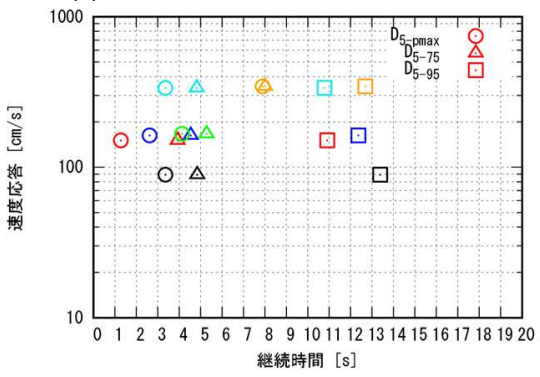

(d) $T=3.02 \mathrm{~s}$ における結果

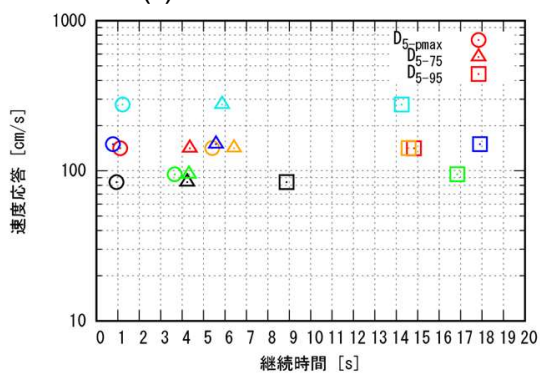

(g) $T=6.03 \mathrm{~s}$ における結果

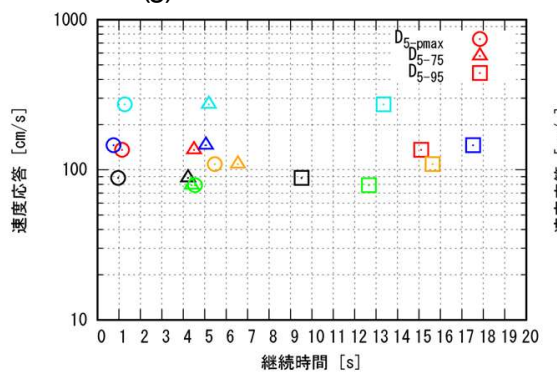

(j) $T=9.12 \mathrm{~s}$ における結果

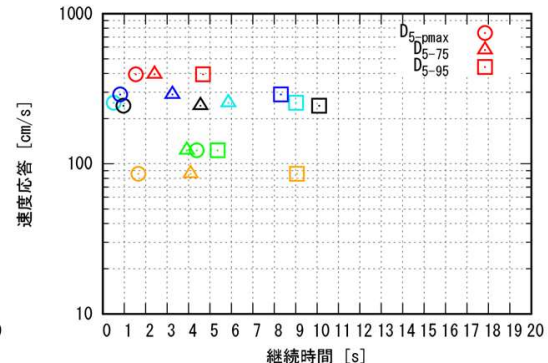

(b) $T=1.00 \mathrm{~s}$ における結果

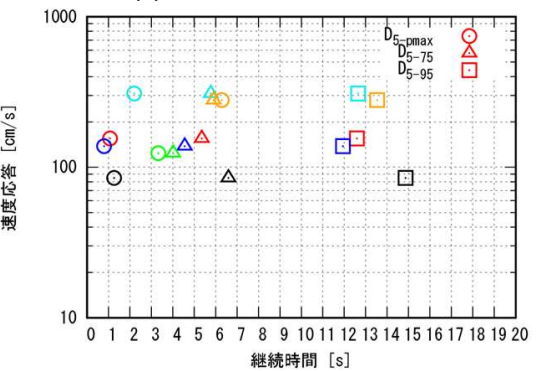

(e) $T=3.98 \mathrm{~s}$ における結果

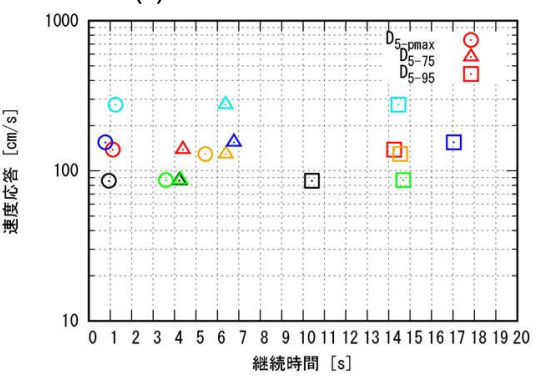

(h) $T=6.92 \mathrm{~s}$ における結果

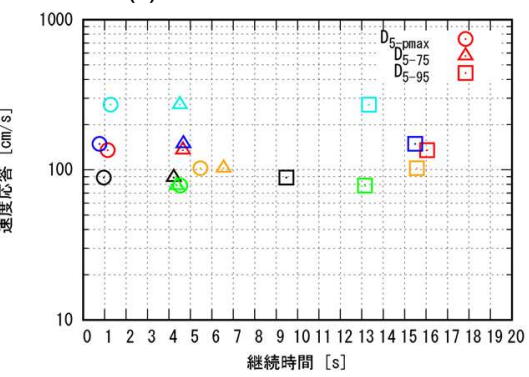

(k) $T=10.00$ sにおける結果

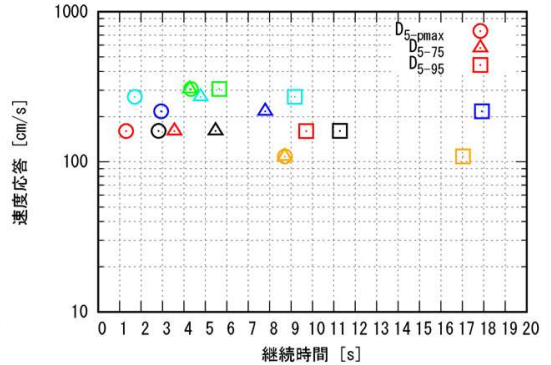

(c) $T=2.00 \mathrm{~s}$ における結果

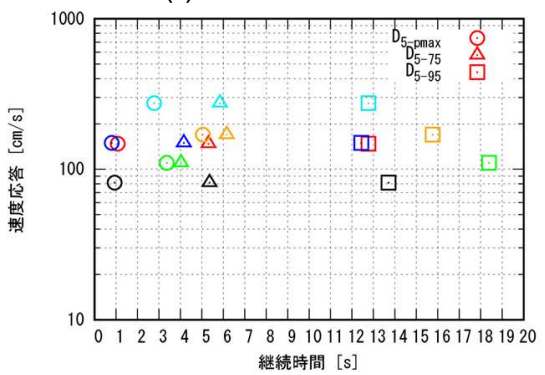

(f) $T=5.01 \mathrm{~s}$ における結果

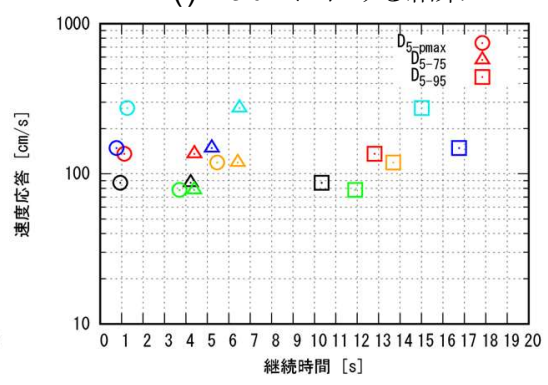

(i) $T=7.94 \mathrm{~s}$ における結果

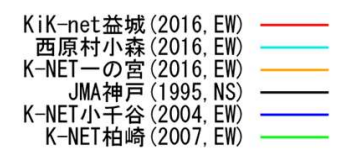

図-11 パルス波の動的効果の比較

えられる。

\section{5. 複数記録間での動的効果の比較}

前章では経時特性に着目し，パルス波のもたらす動的 効果について考察を行った. 1.でも述べたが，本研究で はごく短時間で最大応答に至らせる「衝撃的効果」に着 目している，そこで本章では，振幅特性についても定量 化し，経時特性と振幅特性を総合的に評価し，複数の記 録で比較を行う.

前章で用いた 2016 年熊本地震本震の 3 記録に加え, JMA 神戸（1995 年, NS 成分），K-NET 小千谷（2004 年,
NIG019, EW 成分）, K-NET 柏崎（2007 年, NIG018, EW 成分）の記録も扱い比較を行う.

図-11 は縦軸に速度応答スペクトルの特定の周期にお

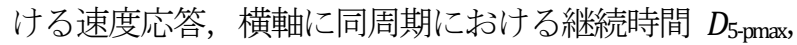
$D_{5-75}, D_{5-95}$ をとった比較である.これらのうち， $D_{5-p m a x}$ （○印）が左上に位置するほど振幅が大きくかつエネル ギー入力が時間的に集中し，パルス波入力の衝撃的効果 が優勢である（逆に右上に位置するほど徐々に応答が増 幅する共振的効果が優勢である）ことを表す.

図-11(a)に各波形の卓越周期における結果を示す. KiK-net 益城, 西原村小森は振幅レベルが大きく, 最大 速度応答に達するまでの継続時間 $D_{5-p m a x}$ が $1.5 \sim 2 \mathrm{~s}$ 程度で あり，衝撃的効果が表れているといえる. KiK-net 益城 
が最も左上に位置することから，卓越周期における衝撃 的効果が最も強かったことが分かる．JMA 神戸につい ては速度応答が他よりも小さいものの， $D_{5-\text { pmax }}$ は $1 \mathrm{~s}$ 程度 で非常に短い，西原村小森では $D_{5 \text {-pmax }}$ と $D_{5-75}$ がほぼ等し $<2 \mathrm{~s}$ 程度であり, エネルギー入力が急速で短時間に最 大応答に達したことが見て取れる。これは図-4で確認さ れたとおりである．K-NET 小千谷は速度応答が極めて大 きく, $D_{5 \text {-pmax }}$ は $3.5 \mathrm{~s}$ 程度である. 6 記録中で最も卓越周期 が短いことから, 波数の増加に伴い共振的に応答が増幅 したと考えられる．K-NET柏崎に関しては全記録の中間 的な位置にある.

4.で述べたように，長周期領域において特徴的な衝撃 的効果が見られたため，周期 1〜10s をほぼ 1s 刻夕に取 り，対象周期を揃えた比較例を図-11(b)〜(k)に示す. 長 周期領域の全体的な傾向として, KiK-net 益城, 西原村 小森, K-NET 小千谷, JMA 神戸は $D_{5-\text { pmax }}$ が 1 〜s 程度で あり，他の 2 記録よりも短いことが挙げられる.

特に $T=6.03 \mathrm{~s}$ よりも長周期側では, 長周期領域の衝撃 的効果の特徴が影著に表れている. 図-11(g)に示す周期 $T=6.03 \mathrm{~s}$ を例に挙げる. 西原村小森, KiK-net 益城, KNET 小千谷，JMA 神戸は $D_{5 \text {-pmax }}$ が $1 \mathrm{~s}$ 程度である。また, KiK-net 益城, K-NET 小千谷は速度応答が $100 \mathrm{~cm} / \mathrm{s}$ を超え る. 西原村小森では速度応答が約 $300 \mathrm{~cm} / \mathrm{s}$ であり, 極め て高い振幅レベルを示す. 周期 $T=6.03 \mathrm{~s}$ における衝撃的 効果が最も強いといえる.

また, 周期 $T=6.03 \mathrm{~s}$ よりも長周期側では KiK-net益城, 西原村小森, K-NET 小千谷, JMA神戸のプロットが類似 している. $D_{5 \text {-pmax }}$ を示す○印は $1 \mathrm{~s}$ 程度であり，ほとんど 変動が見られない. 長周期領域特有の衝撃的効果の強さ が伺える．この周期帯は速度応答スペクトル (図-2参照) のフラットな部分に一致する. 上記の 4 記録は, 4.で述 べたように衝撃的な地動入力がそのまま相対速度応答と して現れ，瞬時に最大速度応答に達したと考えられる。

\section{6. まとめ}

本研究で得られた成果を以下に要約する.

1) 正規化累積エネルギー入力に基づいて地震動の継 続時間を算出する方法を提案し, 累積 $5 \%$ から最大 応答出現までの継続時間 $D 5$-pmax を定義した. その スペクトル表現はパルス波の動的効果を周期ごと に評価・考察するのに有効な手段である.

2) エネルギー入力に基づいて動的効果を評価する指 標として，パルス波が応答の増幅に寄与した割合 を定量化した「エネルギー入力効率」を提案した。 3） パルス波による衝撃的効果の典型例として，長周 期領域において地動入力が相対応答として現れ,
ごく短時間で最大応答に達することと, 継続時間 D5pmax が短くほぼ一定の值を示すことを挙げた.

4) パルス波が卓越する地震動では, 長周期領域の速 度応答スペクトルが高い振幅レベルでフラットな 形を示す．特に西原村小森では, 全周期带を通じ た最大応答レベルに匹敵することがわかった。擬 似速度応答スペクトルではこの特徵は表現されて いない。

5)振幅特性と経時特性の両面を考慮し，パルス波に よる動的効果の比較を行った．長周期領域におい て, KiK-net 益城, 西原村小森, K-NET 小千谷, JMA 神戸では衝撃的効果が優勢であることを示し た.

本研究では加速度記録の EW 成分および NS 成分を取 り扱い, 動的効果の評価・比較を行った. しかし，パル ス波の生成要因としてディレクティビティ効果やフリン グステップが挙げられ 2), これらが動的効果に及ぼす影 響についても十分に検討寸る必要がある. そのため, 今 後は断層直交成分・断層平行成分も取り扱い，地震動記 録の方向についても議論し, パルス波の衝撃的効果につ いてさらに検討を進める方針である.

謝辞: 本研究では, 国立研究開発法人防災科学技術研 究所の K-NET, KiK-net の強震記録を使用させていただ いた．記して謝意を表する次第である.

\section{参考文献}

1) 宮武隆: 断層近傍の強震動パルスの成因, 地震第 2 輯, 第 51 巻, pp.161-170, 1998.

2) 久田嘉章: 活断層と建築の減災対策, 活断層研究, 28 号, pp.77-87, 2008.

3) 三輪田吾郎, 小巻潤平, 佐藤浩太郎, 佐野剛志, 勝 俣英雄, 多幾山法子, 林康裕 : 実大免震建物の擁壁 衝突実験とそのシミュレーション解析, 日本建築学 会構造系論文集, Vol.76, No.663, pp.899-908, 2011.5.

4) 国土交通省国土技術政策総合研究所, 国立研究開発 法人建築研究所 : 平成 28 年 (2016 年) 熊本地震に よる建築物等被害第九次調査報告（速報）（免震建 物に関する調查），2016.6.

5）堺淳一，川島一彦：パルス応答スペクトルに基づく 断層直近地震動の特性, 構造工学論文集, Vol.45A, pp.819-828, 1999.3 .

6) 鈴木恭平, 川辺秀憲, 山田真澄, 林康裕 : 断層近傍 のパルス性地震動特性を考慮した設計用応答スペク トル, 日本建築学会構造系論文集, Vol.75, No.647, pp.49-56, 2010.1.

7) 安井雅明, 西影武知, 見上知広, 刍井功, 鈴木恭平, 林康裕：パルス地震動に対する 1 自由度系最大応答 理論解と応答特性, 日本建築学会構造系論文集,

Vol.75, No.650, pp.731-739, 2010.4.

8) 亀井功, 村瀬詩織, 杉野未奈, 林康裕 : パルス特性 化提案手法を用いた 2016 年熊本地震断層近傍観測波 
のパルス特性評価と応答特性の考察，日本地震工学 会論文集，Vol.18，No.1，pp.18-34，2018.

9) 山本大喜, 能島暢呂：地震動要素としてのパルス波 がもたらす作用に着目した強震動特性の評価法，土 木学会論文集 A1(構造・地震工学), Vol.74, No.4, pp.I_1023-I_1034, 2018.

10) 星谷勝 : 確率論手法による振動解析, 鹿島出版会, 270p., 1974.8.

11) 防災科学技術研究所強震観測管理室 : K-NET 柏崎 $(\mathrm{N}$ IG018)に関して, 2007.8.http://www.kyoshin.bosai.go.j p/kyoshin/topics/chuetsuoki20070716/K-NET_Kashiwaz aki.pdf (2018 年 11 月 2 日閲覧)

12）秋山宏：エネルギーの釣合に基づく建築物の耐震設 計，技報堂出版，228p.，1999.11。

13）加藤勉, 秋山宏 : 強震による構造物へのエネルギ入 力と構造物の損傷, 日本建築学会論文報告集, 第 235 号, pp.9-18, 1975.9.

14) 大井謙一, 高梨晃一, 本間靖章 : 地震動のエネルギ 一入力率スペクトル，日本建築学会構造系論文報告 集，第 420 号, pp.1-7, 1991.2.

15) 井上範夫, 堀則男, 中村孝也 : $\mathrm{RC}$ 構造物の応答に 対する地震動のエネルギー入力性状の影響，コンク
リート工学年次論文報告集, Vol.19, No.2, pp.531536, 1997.

16）井林康, 中沢正利, 尾坂芳夫, 鈴木基行 : 地震入力 総エネルギーおよび地震入力単位エネルギーを考慮 した RC 橋脚の損傷度評価法の提案, 土木学会論文 集，No.676，pp.1-11，2001.5.

17) 内藤伸幸, 松田泰治, 大塚久哲 : 地震入力エネルギ 一に基づく模擬地震波の作成について, 地震工学研 究発表会講演論文集，Vol.26，pp.1149-1152，2001.8.

18) Trifunac, M. D. and Brady, A. G.: A study on the duration of strong earthquake ground motion, BSSA, Vol.65, No.3, pp.581-626, 1975.

19) 能島暢呂：累積パワーに基づく地震動継続時間の経 験的予測式の構築, 日本地震工学会論文集, Vol.15, No.6, pp.25-43, 2015.

20）能島暢呂, 久世益充，高島拓也：地震動の経時特性 の特徵抽出と階層的クラスター分析による分類, 日 本地震工学会論文集, 第 17 巻, 第 2 号, pp.2_1282_141, 2017.

(2018.11.2 受付, 2019.2.4 修正, 2019.2.17 受理)

\section{EVALUATION OF IMPULSIVE EFFECT OF PULSE WAVE BY USE OF ENERGY INPUT TO STRUCTURES}

\section{Taiki YAMAMOTO and Nobuoto NOJIMA}

By use of energy input to structure, a new definition of strong motion duration is proposed. On this basis, dynamic effects of pulse waves have been characterized with emphasis on the impulsive effects. Strong motion records observed at KiK-net Mashiki and Nishihara Village (The 2016 Kumamoto Earthquake) have short duration at each predominant period of the velocity response spectra. In long-period range, peak velocity response is reached in extremely short time and occurs almost simultaneously regardless of the period. As a result, velocity response spectra remain high and flat in wide range of long-period. Such impulsive effects are considered to be representative of the pulse waves. Considering both amplitude and duration, dynamic effects have been compared among various records. In long-period range, impulsive effects are found to be dominant in KiK-net Mashiki, Nishiharamura, K-NET Ojiya (the 2004 Niigata-ken Chuetsu Earthquake) and JMA Kobe (the 1995 Hyogo-ken Nambu Earthquake). 